\title{
Asymmetric facial skin viscoelasticity during climacteric aging
}

This article was published in the following Dove Press journal:

Clinical, Cosmetic and Investigational Dermatology

II April 2014

Number of times this article has been viewed

\section{Gérald E Piérard' \\ Trinh Hermanns-Lê ${ }^{\prime}$ \\ Ulysse Gaspard ${ }^{2}$ \\ Claudine Piérard- \\ Franchimont ${ }^{1}$ \\ 'Laboratory of Skin Bioengineering and Imaging, Department of Clinical Sciences, University of Liège, \\ ${ }^{2}$ Department of Gynecology and Obstetrics, University Hospital of Liège, Liège, Belgium}

Correspondence: Gérald E Piérard Laboratory of Skin Bioengineering and Imaging, University Hospital of Liège, B-4000 Liège, Belgium

Tel +3243662408

Fax +32 43662976

Email gerald.pierard@ulg.ac.be
Background: Climacteric skin aging affects certain biophysical characteristics of facial skin. The purpose of the present study was to assess the symmetric involvement of the cheeks in this stage of the aging process.

Methods: Skin viscoelasticity was compared on both cheeks in premenopausal and postmenopausal women with indoor occupational activities somewhat limiting the influence of chronic sun exposure. Eighty-four healthy women comprising 36 premenopausal women and 48 early post-menopausal women off hormone replacement therapy were enrolled in two groups. The tensile characteristics of both cheeks were tested and compared in each group. A computerized suction device equipped with a $2 \mathrm{~mm}$ diameter hollow probe was used to derive viscoelasticity parameters during a five-cycle procedure of 2 seconds each. Skin unfolding, intrinsic distensibility, biological elasticity, and creep extension were measured.

Results: Both biological elasticity and creep extension were asymmetric on the cheeks of the post-menopausal women. In contrast, these differences were more discrete in the premenopausal women.

Conclusion: Facial skin viscoelasticity appeared to be asymmetric following menopause. The possibility of asymmetry should be taken into account in future studies of the effects of hormone replacement therapy and any antiaging procedure on the face in menopausal women.

Keywords: climacteric aging, biomechanics, photoaging, skin unfolding, biological elasticity, skin tensile properties

\section{Introduction}

The noticeable age of individuals is largely perceived from the appearance of facial skin. On sun-exposed areas, the main characteristics of the aging process are commonly referred to as photoaging. ${ }^{1}$ Typically there are progressive changes leading to mottled subclinical melanoderma, ${ }^{2,3}$ followed by progressive laxity, withering, and wrinkling of the skin. The deleterious effect of ultraviolet light on specific skin structures is beyond doubt. ${ }^{4}$ In addition, endocrine factors are clearly involved in the dermal thinning that occurs during estrogen reduction in the climacteric period. ${ }^{5-11}$ Hence, hormonal aging with impaired tissue trophicity is likely superimposed on the effects of chronic sun exposure during the global process of facial skin aging. In fact, increasing atrophic skin withering and loosening is commonly associated with coarse wrinkling at different skin sites during climacteric aging. ${ }^{5}$

It is established that a computerized suction device applied to the skin can identify a progressive increase in skin distensibility on stress-versus-strain recordings. ${ }^{12,13}$ Global skin deformability typically combines initial unfolding of the skin followed by potential intrinsic distensibility of the connective tissue. 
The aim of the present intraindividual study conducted in premenopausal and post-menopausal women was to compare the biomechanical properties of the skin on both cheeks. Viscoelastic properties were compared using a noninvasive computer-driven suction device.

\section{Materials and methods}

The study was approved by the ethics committee at our institution, and was performed in accordance with the Declaration of Helsinki. Similar studies had not been performed before, so calculation of a minimum adequate size for groups of volunteers was difficult. Eligible participants were enrolled when they attended for a routine checkup at the hospital. A total of 84 healthy Caucasian women from Western Europe without any past history or signs of skin disease were enrolled over a 5 -year period. The only selection criterion was a body mass index (weight $[\mathrm{kg}] /$ height $\left[\mathrm{m}^{2}\right]$ ) in the range of $19-23$, ie, the normal weight range for women in Western Europe. For one month before measurements were taken, the women were required not to apply cosmetics or any other over-the-counter formulation to the face. The women signed their informed consent after being given a full explanation of the study procedure. They were divided into two groups according to age, ie, premenopausal, including 36 women of mean age $43 \pm 1$ (41-45) years, and menopausal, including 48 women of mean age $54 \pm 2(51-56)$ years who were not on hormone replacement therapy.

Objective noninvasive assessments of skin tensile strength were performed on both cheeks using a Cutometer ${ }^{\circledR}$ MPA 580 (Courage + Khazaka Electronic GmbH, Cologne, Germany) with a hollow probe centered by a $2 \mathrm{~mm}$ diameter suction aperture. An additional outer concentric $35 \mathrm{~mm}$ diameter steel guard ring was fixed to the skin using doublesided adhesive film. Following a previously described procedure, ${ }^{12,13}$ adhesive tapes (acrylic paper or silicone) were placed in a crosswise pattern between the outer guard ring and the probe. A repeat steep suction procedure with time-versusstrain recording was used. A total of five cycles of 2-second traction under 400 mbar negative pressure was applied, separated by 2 -second relaxation phases. The biomechanical parameters were similar to those defined previously, ${ }^{12}$ and are summarized in Figure 1. Data were tabulated according to age group, with measurements performed at symmetric cheek skin sites in all volunteers.

Maximum skin deformation (MD), a measure of progressive skin distensibility, was recorded for each cycle of suction. The difference between the fifth and first cycle (MD5 - MD1) was calculated to define the creep extension corresponding to skin unfolding. ${ }^{12}$ Similarly, the residual deformation (RD) was recorded at the end of each cycle. The difference between the two extreme cycles (RD5 - RD1), corresponding to a change in skin resiliency, was calculated. The biological elasticity corresponding to the capacity of the skin to recover its shape after deformation was established following $10^{2}$ (MD1 - RD1) $\mathrm{MD}^{-1}$. The biological elasticity was recorded for the initial cycle. We then explored the possible symmetry of biomechanical properties between the cheeks.

Measurements of each biomechanical parameter were averaged in each group of subjects. Differences and percentage variations were calculated for both groups of women. Statistical comparisons were done using the paired Student's $t$-test. A $P$-value $<0.05$ was considered to be statistically significant.

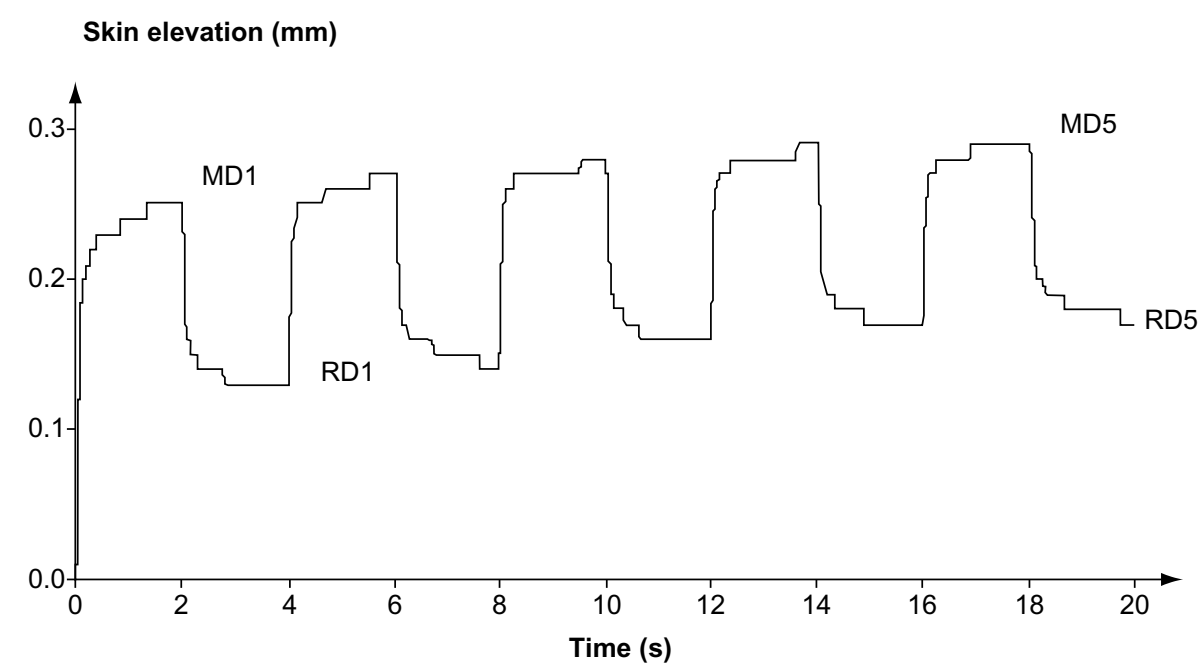

Figure I Recorded mechanical parameters. Examples of variations in elevation of skin over time (pressure 400 mbar; on 2 seconds; off 2 seconds; five repeats; diameter 2 mm). Notes: MDI represents maximum deformation of the skin at the end of the first traction ( 2 seconds); RD represents residual deformation of the skin during the first cycle (4 seconds); MD5 represents maximum deformation of the skin at the end of the fifth traction (I8 seconds); RD5 represents residual deformation of the skin at completion of the fifth traction (20 seconds). 


\section{Results}

Globally, the time-versus-elevation cycle relationships for the repeated steep suction procedure were similar in both groups of volunteers. However, the aspects were not identical on both cheeks, and the influence of age and menopausal status was apparent.

The values for the biomechanical parameters were indeed different in both groups of women (Table 1). The creep extension value, corresponding to MD5 - MD1, was significantly $(P<0.05)$ more prominent in post-menopausal women than in premenopausal women. In the menopausal group, the changes were most evident $(P<0.01)$ for the increase in RD5 - RD1 and the decrease in biological elasticity.

The intraindividual differences in biomechanical parameter values between both cheeks are shown according to age group (Table 2). Between-cheek differences in skin viscoelasticity were minimal in premenopausal women. The differential values for each parameter between both cheeks were significantly larger in the post-menopausal women than in the younger women. The differences were more prominent for biological elasticity in post-menopausal women. Six examples (Figure $2 \mathrm{~A}$ to $\mathrm{F}$ ) are presented.

\section{Discussion}

The Cutometer suction method allows measurement of the viscoelasticity of human skin. In order to obtain accurate, reproducible, and valid data, the measurements must be carried out under controlled conditions, where various parameters, such as vacuum intensity, probe aperture, time of application, and relaxation need to be determined. The influence of physiological parameters such as aging, anatomic skin sites, and sex, as well as the possible efficacy of

Table I Biomechanical parameters (mean \pm standard deviation) combining data from each set of cheeks in premenopausal $(n=72)$ and post-menopausal $(n=96)$ women

\begin{tabular}{|c|c|c|c|}
\hline Parameter & $\begin{array}{l}\text { Premenopausal } \\
\text { women }\end{array}$ & $P$-value & $\begin{array}{l}\text { Post-menopausal } \\
\text { women }\end{array}$ \\
\hline \multicolumn{4}{|l|}{$\begin{array}{l}\text { Progressive skin } \\
\text { distensibility }\end{array}$} \\
\hline MD5 - MDI (mm) & $0.02 \pm 0.01$ & $<0.05$ & $0.04 \pm 0.02$ \\
\hline \multicolumn{4}{|l|}{$\begin{array}{l}\text { Changes in skin } \\
\text { resiliency }\end{array}$} \\
\hline RD5 - RDI (mm) & $0.05 \pm 0.01$ & $<0.01$ & $0.08 \pm 0.02$ \\
\hline \multicolumn{4}{|l|}{ Biological elasticity } \\
\hline $\begin{array}{l}\mathrm{I}^{2}(\mathrm{MDI}-\mathrm{RDI}) \\
\mathrm{MDI}^{-1}(\%)\end{array}$ & $73.3 \pm 2.8$ & $<0.01$ & $64.9 \pm 3.7$ \\
\hline
\end{tabular}

Notes: MD5 - MDI, difference in maximum skin deformation between the fifth and first cycle of suction; RD5 - RDI, difference in residual deformation between the fifth and first cycle of suction.
Table 2 Intraindividual differential values in biomechanical parameters (mean \pm standard deviation) between the cheeks in premenopausal $(n=36)$ and post-menopausal $(n=48)$ women

\begin{tabular}{|c|c|c|c|}
\hline $\begin{array}{l}\text { Parameter } \\
\text { (differential } \\
\text { values) }\end{array}$ & $\begin{array}{l}\text { Premenopausal } \\
\text { women }\end{array}$ & $P$-value & $\begin{array}{l}\text { Post- } \\
\text { menopausal } \\
\text { women }\end{array}$ \\
\hline \multicolumn{4}{|l|}{$\begin{array}{l}\text { Progressive skin } \\
\text { distensibility }\end{array}$} \\
\hline MD5 - MDI (mm) & $0.01 \pm 0.01$ & $<0.05$ & $0.03 \pm 0.03$ \\
\hline \multicolumn{4}{|l|}{$\begin{array}{l}\text { Changes in skin } \\
\text { resiliency }\end{array}$} \\
\hline RD5 - RDI (mm) & $0.02 \pm 0.01$ & $<0.05$ & $0.04 \pm 0.03$ \\
\hline \multicolumn{4}{|l|}{ Biological elasticity } \\
\hline $\begin{array}{l}I^{2} \text { (MDI - RDI) } \\
M^{-1}(\%)\end{array}$ & $2.31 \pm 1.6$ & $<0.01$ & $5.44 \pm 2.4$ \\
\hline
\end{tabular}

dermocosmetic treatments, can be quantitatively determined using this suction method. A number of earlier studies have assessed the mechanical properties of skin across a woman's lifetime, ${ }^{14-18}$ with some focused on natural menopause ${ }^{19-21}$ and excluding premature and early menopause. ${ }^{22}$

The present study compared skin viscoelasticity on both cheeks in middle-aged women. During repeated cycles of measurement, deformation versus time curves obtained for the second and subsequent deformation cycles were similar to the first cycle, but progressively shifted upwards as a consequence of increased RD. The behavior of facial skin with regard to mechanical stress often appeared to be asymmetric, particularly in menopausal women. Such differences were probably related at least in part to unequal solar elastosis. However, other dermal extracellular matrix components are possibly involved as well. ${ }^{23}$ In addition, tethering of the dermis to underlying structures was involved in the unfolding ability in response to earth's gravity combined with changes in intrinsic dermal distensibility.

From an engineering standpoint, both the skin and subcutaneous tissue act as interconnected load-transmitting structures, and are subject to a variety of intrinsic and environmental influences. Asymmetric changes in cutaneous viscoelasticity have not been explored in detail thus far in the scientific literature. However, they are important and likely related to environmental effects. This condition is sometimes referred to as "truck driver's skin" due to the constant orientation of the hemiface to sun exposure when sitting in the driver's cab. Ultraviolet light appears then to be a most prominent effector agent. Our study design did not allow identification of the relative impact of potentially diverse causes affecting global creep extension corresponding to MD5 - MD1. It remains that 


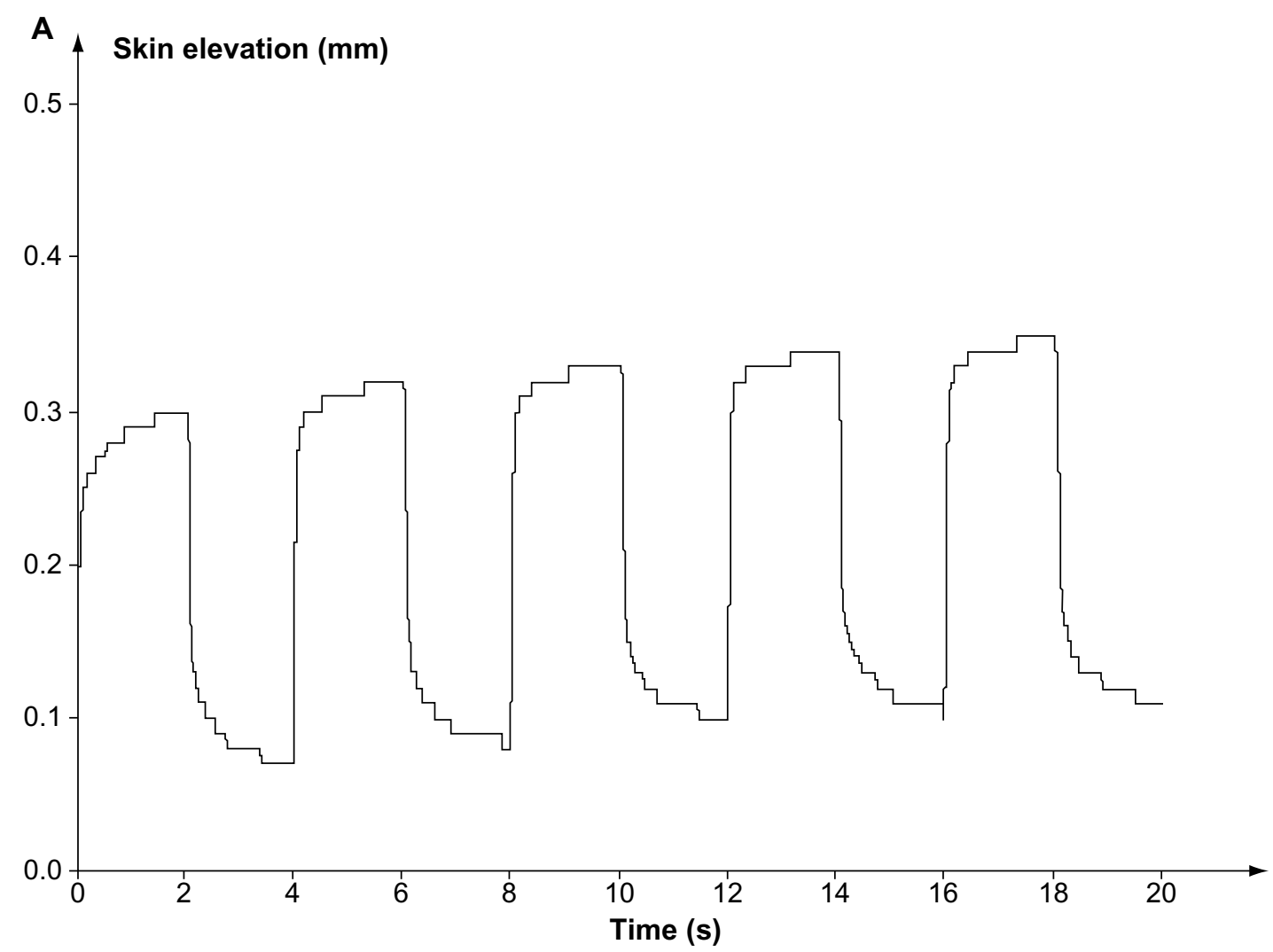

B

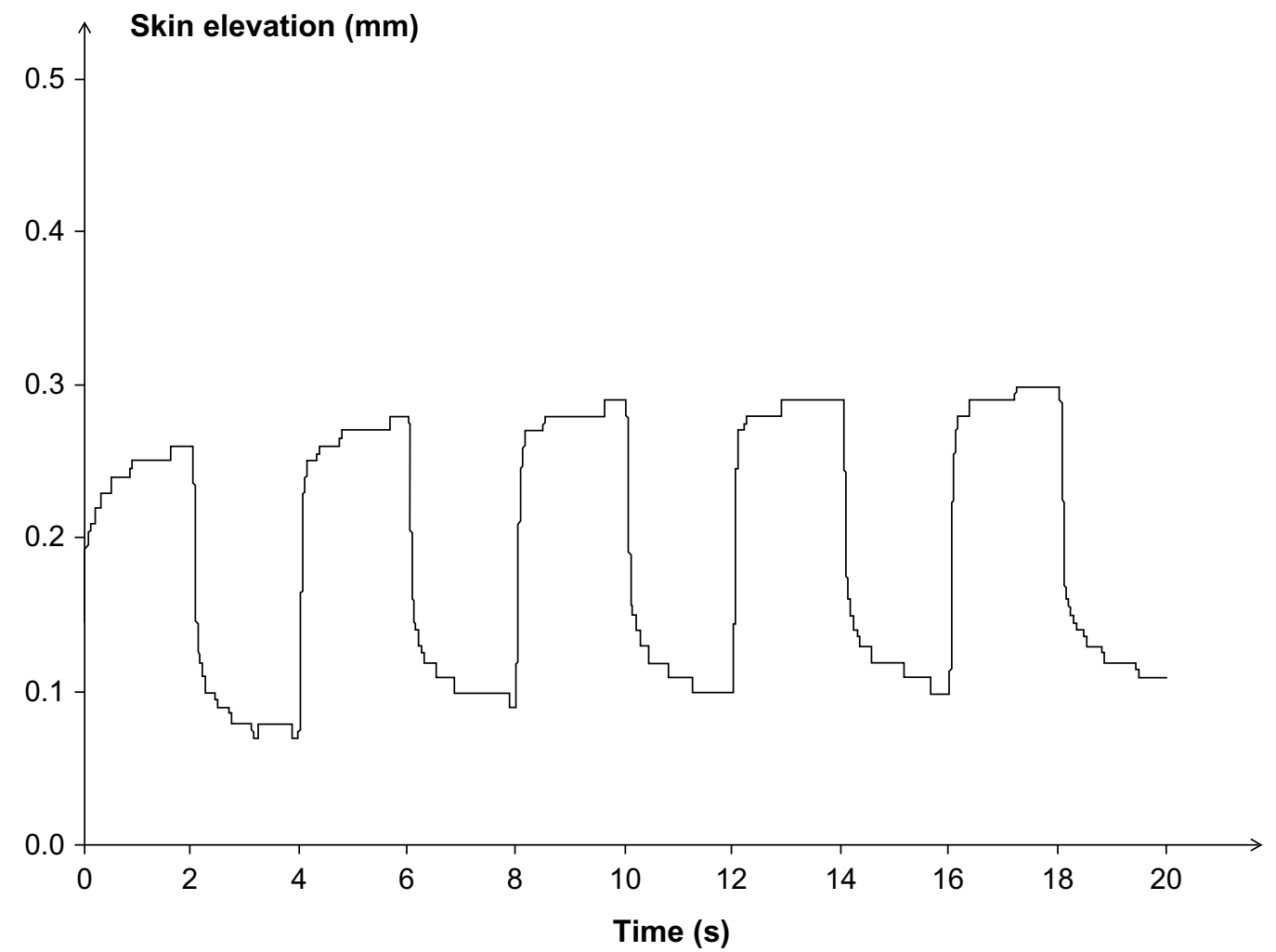

Figure 2 (Continued) 


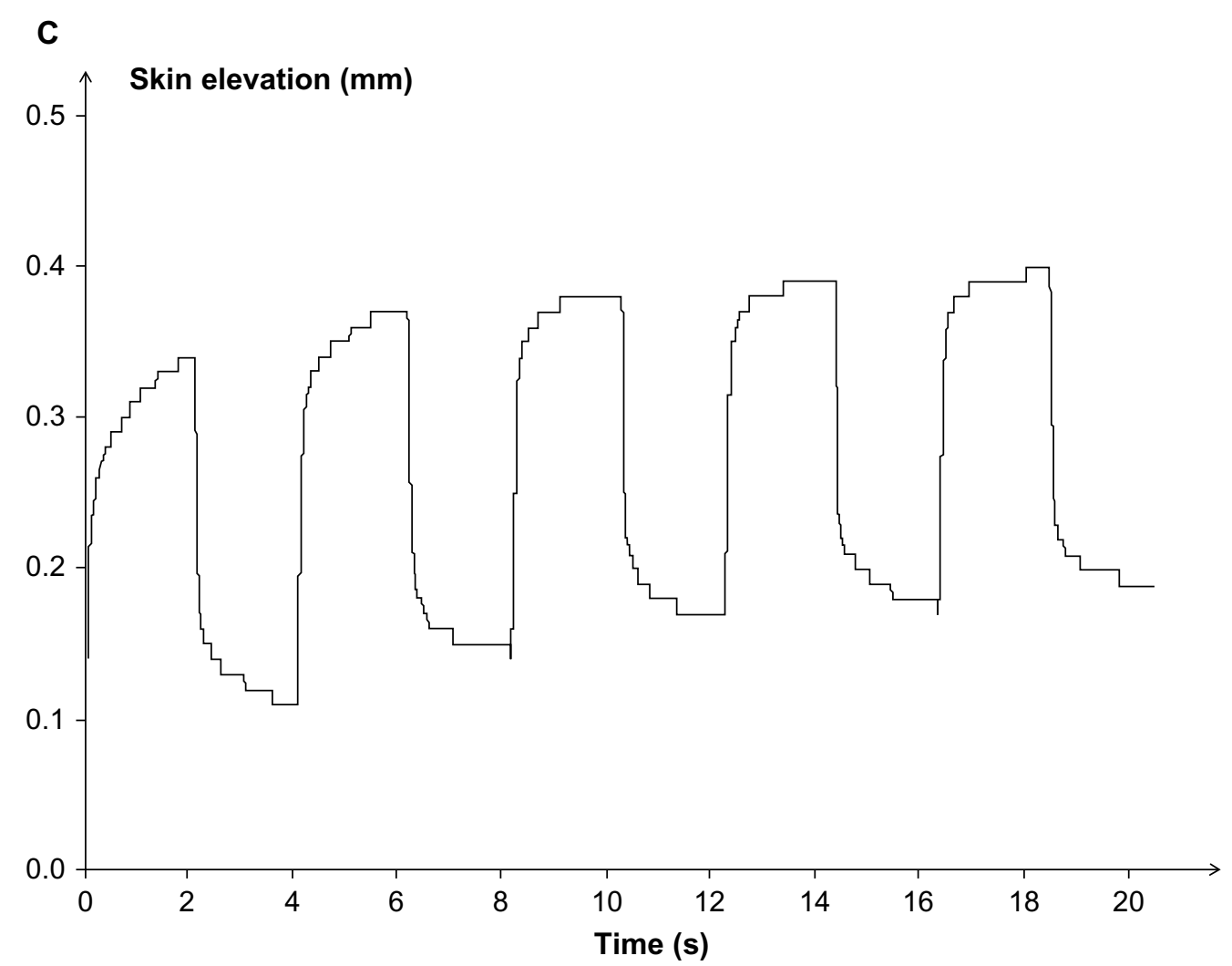

D

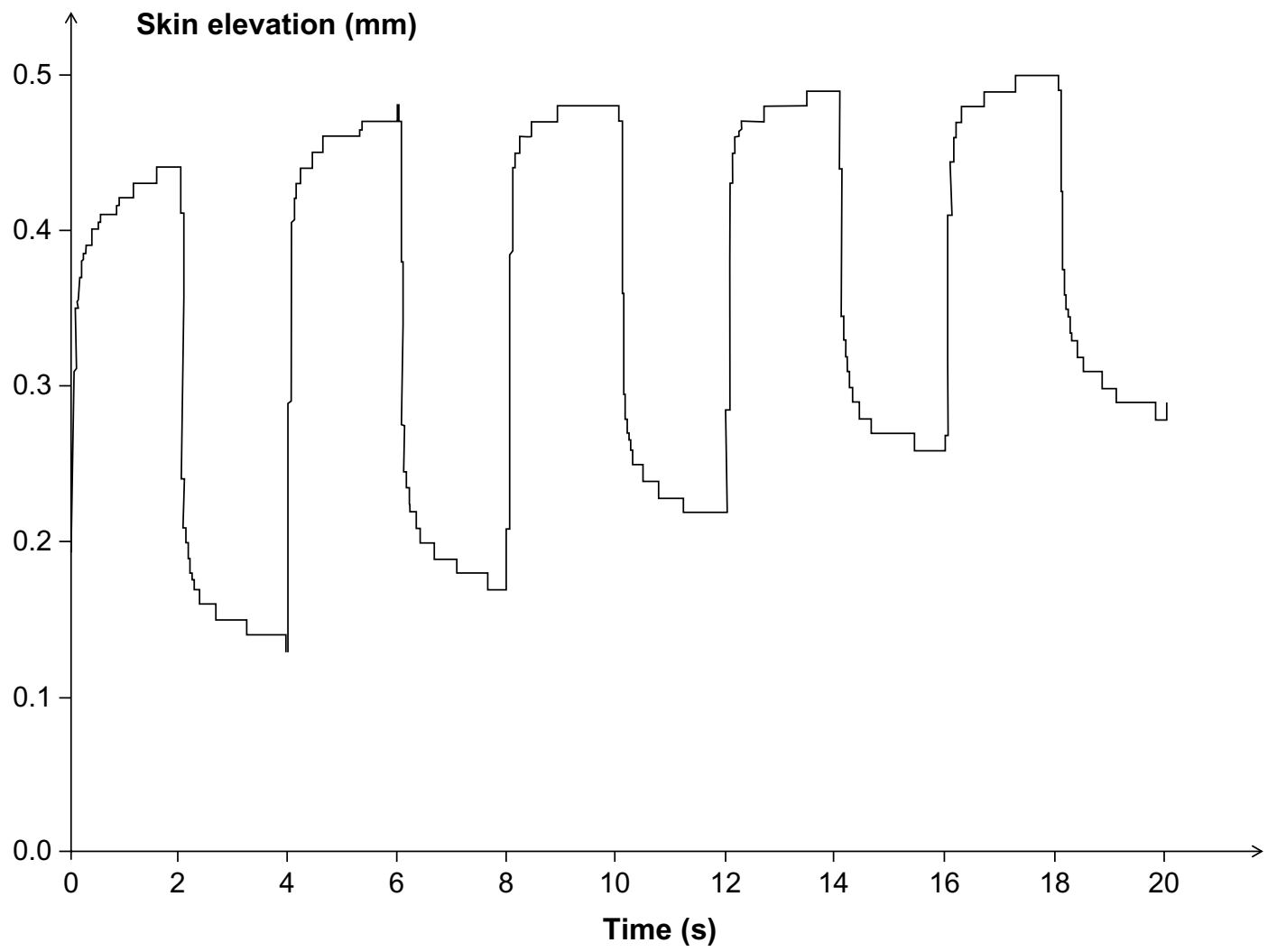

Figure 2 (Continued) 

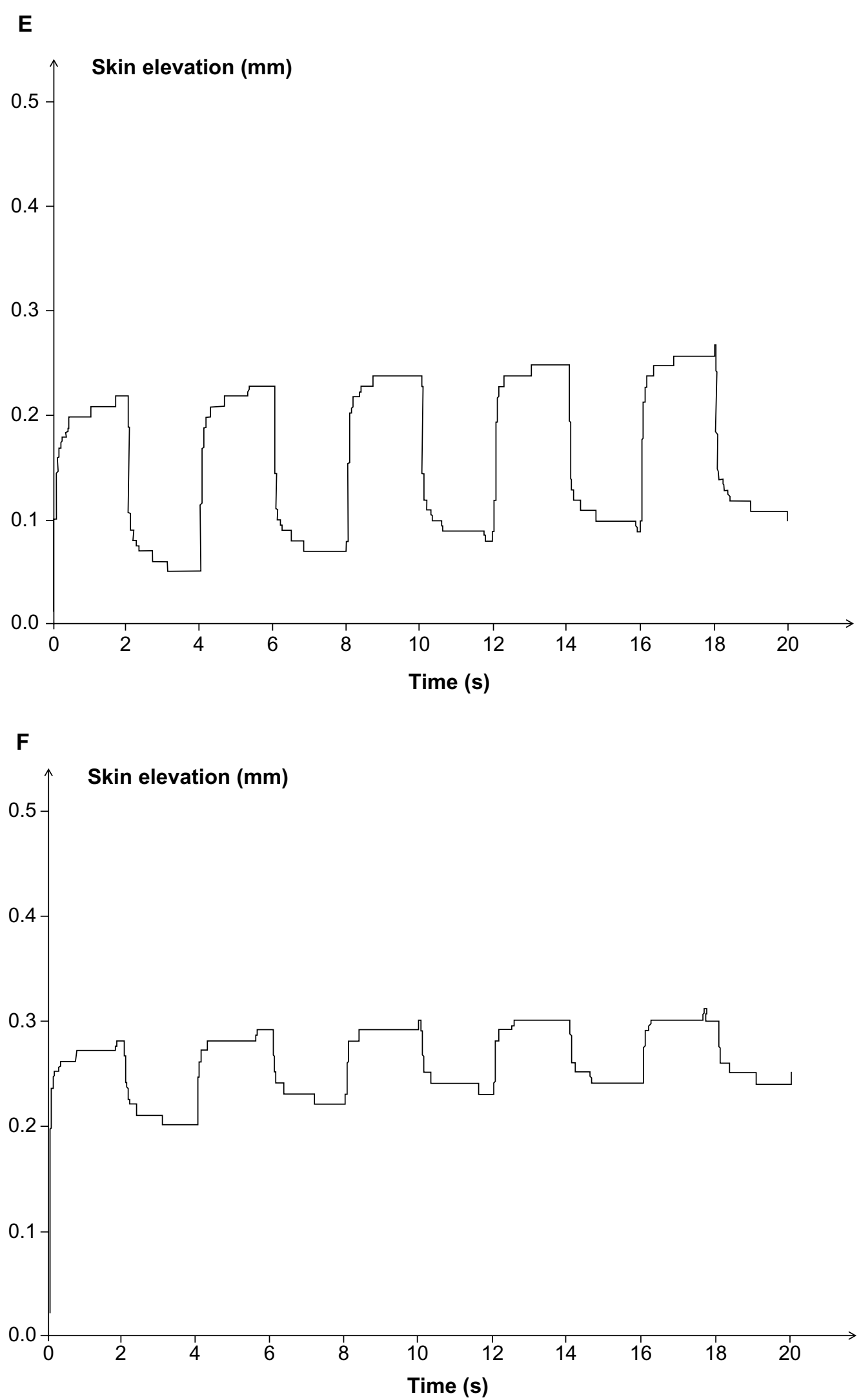

Figure 2 Recordings of skin tensile characteristics on cheeks during a five-cycle procedure of suction.

Notes: MD5 - MDI, difference in maximum skin deformation between the fifth and first cycle of suction; RD5 - RDI, difference in residual deformation between the fifth and first cycle of suction. (A and B) Moderate MDI increase on cheek a compared with cheek b. (C and D) Asymmetry with marked increased in MDI, MD5, and RDI in cheek $d$ compared with cheek c. (E and F) Marked asymmetry with prominent increase in MDI, MD5, RDI, and RD5 in cheek $f$ compared with cheek e. 
some of the biomechanical parameters provide information supporting specific aspects of the structure-function relationship in the skin connective tissue. For instance, the progressive creep extension seen during successive suction cycles was probably in part related to intrinsic dermal distensibility. In contrast, the progressive increase in $\mathrm{RD}$ during the testing procedure was attributable to global skin unfolding, in part related to the sliding capacity of the hypodermis.

Climacteric aging refers to the period in a woman's life corresponding to the perimenopause. This stage of life commonly initiates the atrophic skin withering and slackness responsible for changes in viscoelasticity of the dermal connective tissue. Some women benefit from hormone replacement therapy in terms of controlling these unpleasant climacteric changes. Hormone replacement therapy in particular has the potential to correct the functional damage seen in dermal tensile strength. ${ }^{21}$ A number of methods can be used to assess specific characteristics of the skin. The suction method is used by most investigators. Skin distensibility appears to increase during menopause regardless of whether the woman is on hormone replacement therapy. In contrast, biological elasticity decreases significantly in the absence of hormone replacement therapy. ${ }^{21}$ Further studies are needed to explore the role of dermocosmetic products and cosmeceuticals that might improve the viscoelastic characteristics of skin after menopause.

\section{Acknowledgments}

This work was supported by a grant from "Fonds d'Investissement de la Recherche Scientifique" at the University Hospital of Liège. The authors appreciate the excellent secretarial assistance of Ida Leclercq and Marie Pugliese.

\section{Disclosure}

The authors report no conflicts of interest directly relevant to the content of this paper.

\section{References}

1. Gilchrest BA. Photoaging. J Invest Dermatol. 2013;133:E2-E6.

2. Petit L, Fogouang L, Uhoda I, Smitz S, Piérard-Franchimont C, Piérard GE. Regional variability in mottled subclinical melanoderma in the elderly. Exp Gerontol. 2003;38:327-331.

3. Hermanns-Lê T, Piérard-Franchimont C, Piérard GE. Scrutinizing skinfield melanin patterns in young Caucasian women. Expert Opin Med Diagn. 2013;7:455-462.
4. Syed DN, Khan MI, Shabbir M, Mukhtar H. MicroRNAs in skin response to UV radiation. Curr Drug Targets. 2013;14:1128-1134.

5. Piérard GE. The quandary of climacteric skin ageing. Dermatology. 1996;193:273-274.

6. Piérard-Franchimont C, Cornil F, Dehavay J, Deleixhe-Mauhin F, Letot B, Piérard GE. Climacteric skin ageing of the face. A prospective longitudinal intent-to-treat trial on the effect of oral hormone replacement therapy. Maturitas. 1999;32:87-93.

7. Raine-Fenning NJ, Brincat M, Muscat-Baron Y. Skin ageing and menopause: implications for treatment. Am J Clin Dermatol. 2003;4: 371-378.

8. Verdier-Sevrain S, Bonte F, Gilchrest BA. Biology of estrogens in skin: implication for skin aging. Exp Dermatol. 2006;15:83-94.

9. Farage MA, Miller KW, Elsner P, Maibach HI. Intrinsic and extrinsic factors in skin ageing: a review. Int J Cosmet Sci. 2008;30:87-95.

10. Farage M, Miller KW, Zouboulis CC, et al. Gender differences in skin aging and the changing profile of the sex hormones with age. J Steroids Horm Sci. 2012;3:1000109.

11. Piérard GE, Humbert P, Berardesca E, Gaspard U, Hermanns-Lê T, Piérard-Franchimont C. Revisiting the cutaneous impact of oral hormone replacement therapy. Biomed Res Int. 2013;2013:971760.

12. Piérard GE, Piérard S, Delvenne P, Piérard-Franchimont C. In vivo evaluation of the skin tensile strength by the suction method. Coping with hysteresis and creep extension. ISRN Dermatol. 2013;2013: 841217.

13. Piérard GE, Hermanns-Lê T, Piérard-Franchimont C. Scleroderma, skin stiffness, assessment using the stress-strain relationship under progressive suction. Expert Opin Med Diagn. 2013;7:119-125.

14. Piérard-Franchimont $\mathrm{C}$, Castelli $\mathrm{D}$, Van Cromphaut I, et al. Tensile properties and contours of aging facial skin. A controlled double-blind comparative study of the effects of retinol, melibiose-lactose and their association. Skin Res Technol. 1998;4:237-243.

15. Piérard GE, Henry F, Castelli D, Ries G. Ageing and rheological properties of facial skin in women. Gerontology. 1998;44:159-161.

16. Ryu HS, Joo YH, Kim SO, Park KC, Youn SW. Influence of age and regional differences on skin elasticity as measured by the cutometer. Skin Res Technol. 2008;14:354-358.

17. Krueger N, Luebberding S, Oltmer M, Streker M, Kerscher M. Agerelated changes in skin mechanical properties, a quantitative evaluation of 120 fermale subjects. Skin Res Technol. 2011;17:141-148.

18. Firooz A, Sadr B, Babakoohi S, et al. Variation of biophysical parameters of the skin with age, gender, and body region. Scientific World Journal. 2012;2012:386936.

19. Li C, Samsioe G, Borgfeldt C, Lidfeldt J, Agardh CD, Nerbrand C. Menopause-related symptoms, what are the background factors? A prospective population-based cohort study of Swedish women (The Women's Health in Lund Area Study). Am J Obstet Gynecol. 2003; 189:1646-1653.

20. Li S, Rosenberg L, Wise LA, Boggs DA, LaValley M, Palmer JR. Age at natural menopause in relation to all-cause and cause-specific mortality in a follow-up study of US black women. Maturitas. 2013;75:246-252.

21. Piérard GE, Hermanns-Lê T, Paquet P, Piérard-Franchimont C. Skin viscoelasticity during hormone replacement therapy for climacteric ageing. Int J Cosmet Sci. 2014;36:88-92.

22. Shuster LT, Rhodes DJ, Gostout BS, Grossardt BR, Rocca WA. Premature menopause or early menopause: long-term health consequences. Maturitas. 2010;65:161-166.

23. Diridollou S, Pavy-Le Traon A, Maillet A, et al. Characterization of gravity-induced facial skin oedema using biophysical measurement techniques. Skin Res Technol. 2000;6:118-127. 


\section{Publish your work in this journal}

Clinical, Cosmetic and Investigational Dermatology is an international, peer-reviewed, open access, online journal that focuses on the latest clinical and experimental research in all aspects of skin disease and cosmetic interventions. All areas of dermatology will be covered; contributions will be welcomed from all clinicians and

basic science researchers globally. This journal is indexed on CAS.

The manuscript management system is completely online and includes a very quick and fair peer-review system, which is all easy to use. Visit http://www.dovepress.com/testimonials.php to read real quotes from published authors.

Submit your manuscript here: http://www.dovepress.com/clinical-cosmetic-and-investigational-dermatology-journal 